\title{
PREDICTING THE AMERICAN BOLLWORM, HELICOVERPA ARMIGERA (HÜBNER) FIELD GENERATIONS AS INFLUENCED BY HEAT UNIT ACCUMULATION \\ EL-MEZAYYEN, G.A. and M.G. RAGAB
}

Plant Protection Research Institute, Dokki, Giza, Egypt

(Manuscript received 23 November 2013)

\begin{abstract}
The present study was conducted in Beni-Suef Governorate under field conditions during the seasons of 2005 and 2006. Results indicated that the population of the American bollworm moths, Helicoverpa armigera (Hübner) had four peaks starting from the $3^{\text {rd }}$ week of May until the $2^{\text {nd }}$ week of September during the two tested seasons. The highest number of moths was recorded during the end of July and the whole August which being $120 \& 154$ moth/trap/35 days and 150 days after cotton planting in both seasons, respectively. The predicted peaks of generations could be detected when the accumulated thermal units recorded 558.18 DD's. The predicted peaks for the detected four generations varied from +2 to -3 days from the observed peaks. For better prediction of the American bollworm the period between the observed and expected peaks should be positive and as short as possible when early preparation of pest control materials are of great important, consequently it could be helpful when IPM control tactics are considered.

Key words:

American bollworm, Helicoverpa armigera, peaks, predicting, generations, thermal units accumulations.
\end{abstract}

\section{INTRODUCTION}

The American bollworm, Helicoverpa armigera (Hübner) known as "tomato fruit worm" is a polyphagous pest that feeds on over 200 host plants and wild species including at least 45 families (Sidde Gowda et al., 2002 \& Ibrahim, 2012).

In Egypt, it is necessary to design an alternative program for controlling this pest which the use of insecticide is considered the most effective method to control such this pest. So, it is becoming very important to find out and develop a program associated to reduce the use of insecticides for human health safety and/or better agroecosystem.

Integrated pest management program involves a system to suppress the pest population which depends on predicting the seasonal population cycles of insects, this had led to the formulation of many mathematical methods (Richmond et al., 1983), which described the developmental rates as function of temperature (Wagner et al., 1984). 
Predicting and monitoring population systems for lepidopterous insect pests by using light or pheromone traps based on heat requirements were reported by Potter et al., 1981, Sing et al., 2004, Dahi, 2007, Amer et al., 2009 and El-Sayed et al., 2009

The objectives of the current research were to:

a. Study the seasonal fluctuations of $H$. armigera moths by using light trap.

b. Predicting of $H$. armigera generations in relation to accumulated heat units.

\section{MATERIALS AND METHDOS}

The study was conducted in Beni-Bekheet village, Beni-Suef governorate, the Arab Republic of Egypt during the seasons of 2005 and 2006. The light trap (Robinson and Robinson, 1950) was fixed on the building of the agricultural association at high of 4 meter above the ground and adjacent to cotton fields. The cotton area adjacent to summer crops such as maize, sunflower, okra and tomato intercropped with cotton. The cotton occupied an area of 35 and 45 feddans in the first and second season, respectively. The cotton variety Giza 80 was planted on the fourth week of March during the two cotton growing seasons.

The daily catch of the American bollworm males and females were collected, counted, identified and recorded. Daily number of the captured moths was accumulated for seven days during both seasons and were presented graphically to determine the population peaks in the successive generations in relation to the accumulated thermal units in degree-days.

To study the prediction possibility in relation to heat units accumulations, the temperature was could be transformed into heat units and serves as a tool for measuring insect population dynamics and predicting the appearance of the American bollworm in the field during the aforementioned two successive seasons. Each season extended from early April to the end of September.

Daily maximum and minimum temperatures were obtained and recorded by Central Laboratory for Agricultural Climate (CLAC). Degree-days (DD) were calculated from the daily maximum and minimum temperature $\left({ }^{\circ} \mathrm{C}\right)$ with developmental threshold $\left(t_{0}\right)$ which has been estimated in the laboratory under constant conditions, where the zero development $\left(t_{0}\right)$ was $10.87^{\circ} \mathrm{C}$ with 557.5 DD's for generation development (Dahi, 2007). The following formula was used for computing the degree-days (DD) according to Richmond et al. (1983) under fluctuation temperatures:

$$
\mathrm{H}=\Sigma \mathrm{Hj}
$$

Where:

$\mathrm{H}=\quad$ Number of heat units to emergence. 


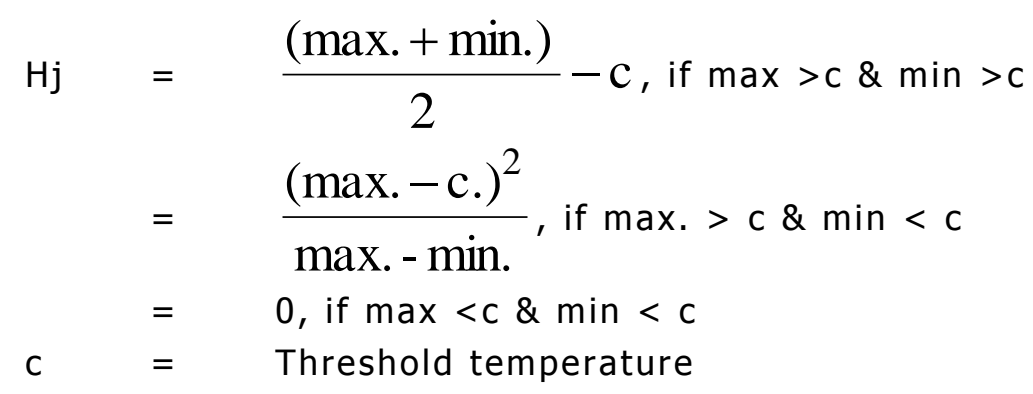

\section{RESULTS AND DISCUSSION}

\section{Seasonal fluctuation of Helicoverpa armigera moths and its relation to cotton planting:}

Figs $(1 \& 2)$ indicate that $H$. armigera moths during the two tested seasons showed four peaks for each. These peaks occurred from the $3^{\text {rd }}$ week of May until the $2^{\text {nd }}$ week of September. The first peak was occurred on $26^{\text {th }}$ and $19^{\text {th }}$ May. The corresponding moths were 16 and 18 moth/trap/week during 2005 and 2006 cotton seasons, respectively, then population fluctuated and increased to reach the second peak on $23^{\text {rd }}$ and $30^{\text {th }}$ June, where the captured moths recorded 32 and 36 moth/trap/week during the first and second season, respectively. The third peak was occurred on $28^{\text {th }}$ July and $4^{\text {th }}$ August, where the trapped moths equal 52 and 41 moth/trap/week in the two tested seasons, respectively. The fourth peak occurred on $8^{\text {th }}$ September where the trapped moths recorded 63 and 39 moth/trap/week during the two seasons of 2005 and 2006, respectively.

It could be noticed that the fourth and the third peak during the two seasons of 2005 and 2006 had the highest number of moths (63 \& 41 moth/trap) than the other two peaks in the first and second seasons, respectively. During the season of 2005, the highest number of moths was recorded during the end of July and whole of August months (120 \& 154 moth/trap) after 150 days cotton planting while the number of moths are the higher in the second season (381 moth/trap) than the first one (349 moth/trap).

These results are in agreement with those obtained by Prasad et al. (2009) in India who reported that both light and pheromone baited traps were effective in monitoring the cotton bollworms, in Seriba, Sekulic et al. (2003) recorded three generations of $\boldsymbol{H}$. armigera from late May until early September. Also, El-Sayed et al. (2009) found three peaks of $H$. armigera occurred from the fourth week of May till the third week of September, while Dahi (2007) and Ibrahim (2012) indicated that $H$. armigera had five peaks from March until November at Fayoum and Qalyoubia governorates, respectively. 


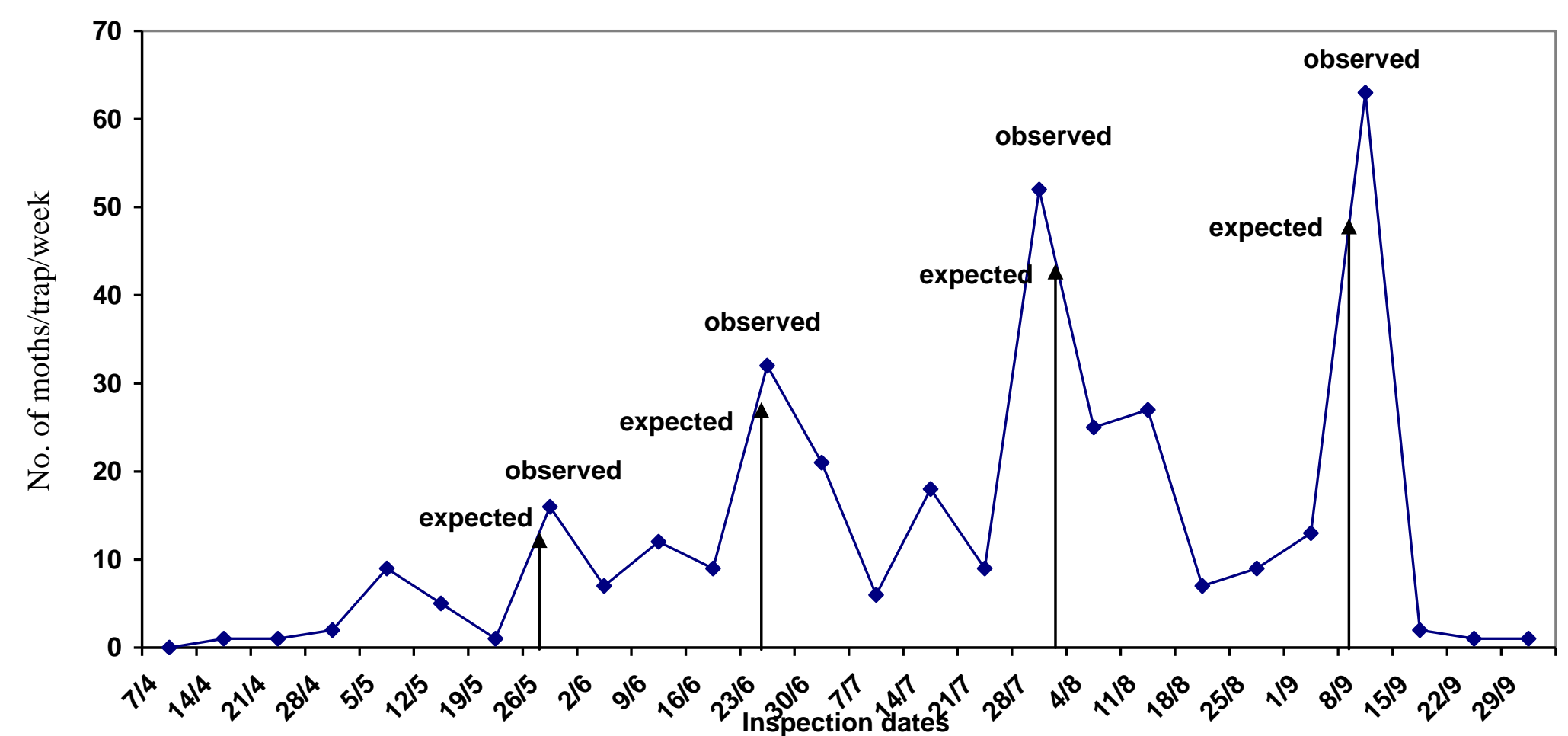

Fig. 1. Deviation between observed and expected annual generations of H. armigera in Beni Suef Governorate during 2005 season 


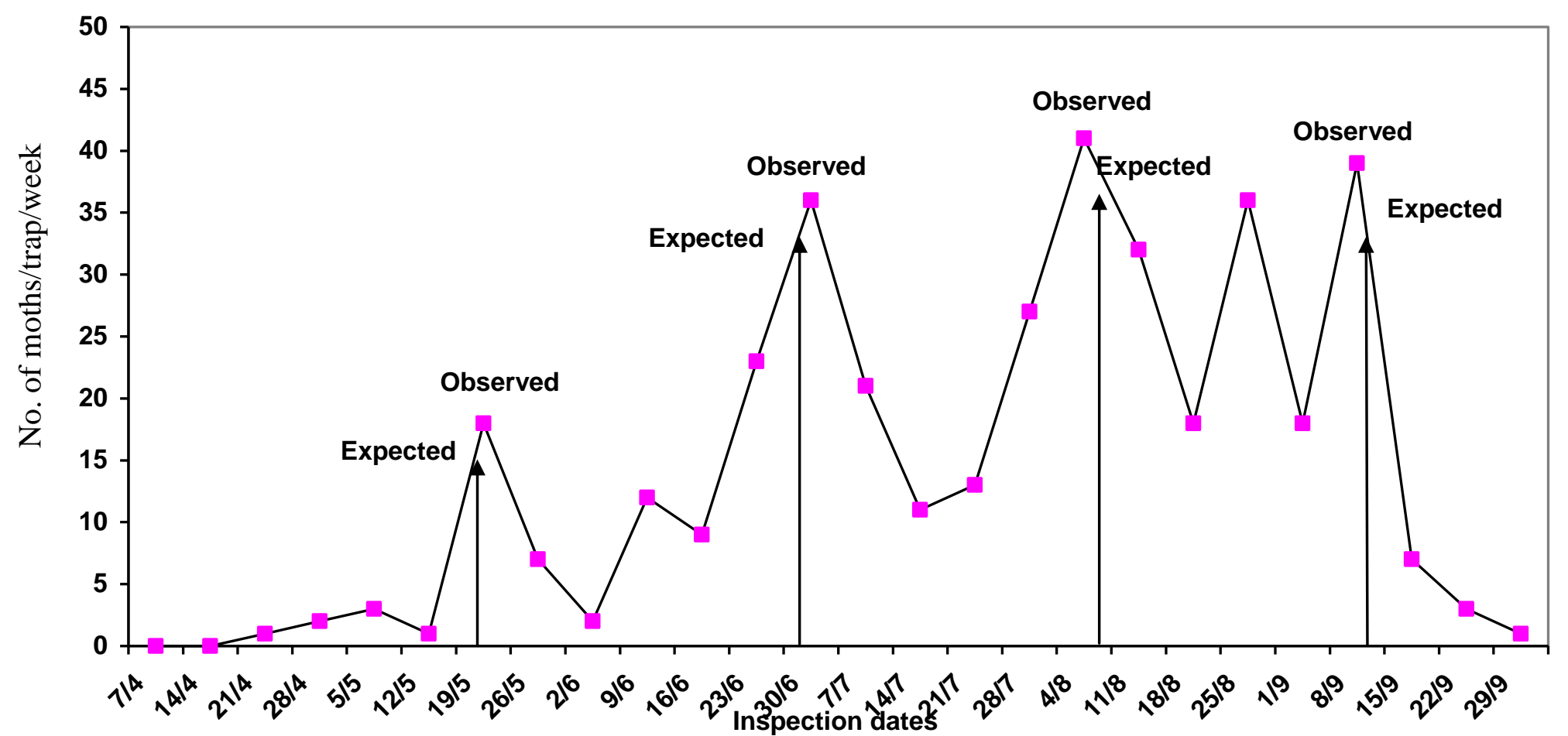

Fig. 2. Deviation between observed and expected annual generations of H. armigera in Beni Suef Governorate during 2006 season 


\section{Prediction of $\boldsymbol{H}$. armigera generations and in relation to accumulated heat units:}

Data presented in Table (1) and Figs. ( $1 \& 2)$ show that the observed peak of the first generation was occurred on $26^{\text {th }}$ and $19^{\text {th }}$ May in 2005 and 2006 seasons, respectively. On the other hand, the expected peak for the same generation was observed on $25^{\text {th }}$ and $18^{\text {th }}$ May at 567.73 and 571.33 DD's during the two seasons of 2005 and 2006, respectively with deviation interval +1 day than the real peak for both 2005 and 2006 seasons.

Table 1. Comparison of the observed and expected $H$. armigera generations monitored with light trap related to accumulated degree days (DD's) in BeniSuef Governorate during 2005 and 2006 seasons.

\begin{tabular}{|c|c|c|c|c|c|}
\hline \multirow{3}{*}{ Seasons } & \multirow{2}{*}{ Generations } & \multicolumn{2}{|c|}{ Generation dates } & Deviation & Accumulated \\
\cline { 3 - 4 } & & Observed & Expected & (days) & $\begin{array}{c}\text { degree-days } \\
\text { (DD's) }\end{array}$ \\
\hline \multirow{4}{*}{2005} & $1^{\text {st }}$ & $26 / 5$ & $25 / 5$ & +1 & 567.73 \\
& $2^{\text {nd }}$ & $23 / 6$ & $22 / 6$ & +1 & 548.31 \\
& $3^{\text {rd }}$ & $28 / 7$ & $31 / 7$ & -3 & 533.14 \\
& $4^{\text {th }}$ & $8 / 9$ & $6 / 9$ & +2 & 574.11 \\
\hline \multirow{4}{*}{2006} & Average & & & +0.25 & 555.82 \\
& $1^{\text {st }}$ & $19 / 5$ & $18 / 5$ & +1 & 571.33 \\
& $2^{\text {nd }}$ & $30 / 6$ & $28 / 6$ & +2 & 550.83 \\
& $3^{\text {rd }}$ & $4 / 8$ & $6 / 8$ & -2 & 551.12 \\
& $4^{\text {th }}$ & $8 / 9$ & $11 / 9$ & -3 & 568.93 \\
\hline & Average & & & -0.5 & 560.55 \\
\hline & Average of & & & -0.25 & 558.18 \\
& two seasons & & & & \\
\hline
\end{tabular}

The real peak of the second generation was occurred on the $23^{\text {rd }}$ and $30^{\text {th }}$ June in the first and second season, while the expected dates of this generation were observed on the $22^{\text {nd }}$ and $28^{\text {th }}$ June with an average of 548.31 and 550.83 DD's during two seasons of 2005 and 2006, respectively. The deviations between the observed and expected peaks were +1 and +2 days earlier for the two seasons, respectively. The observed and expected peaks of the third generation were occurred on $28^{\text {th }}$ July $\& 4^{\text {th }}$ August and $31^{\text {st }}$ July \& $6^{\text {th }}$ August during the two seasons of 2005 and 2006, respectively, when the accumulated heat requirements completed 533.14 and 551.12 DD's during both seasons, respectively. The deviation between the observed and expected peaks were -3 and -2 days later for 2005 and 2006, respectively. 
The actual observed peak of the fourth generation appeared on $8^{\text {th }}$ September for both seasons. The expected dates of this generation occurred on the $6^{\text {th }}$ and $11^{\text {th }}$ September in the first and second season with a deviation intervals of +2 and -3 days when the accumulated degree days were 574.11 and 568.93 DD's in 2005 and 2006, respectively. It could be noticed that the highest number of moths was appeared during this generation on $8^{\text {th }}$ September (63 moth/trap) during the season of 2005 while during the season of 2006, the highest peak was occurred on $4^{\text {th }}$ August (41 moth/trap) during the third generation.

These results are in agreement with those obtained by Potter et al. (1981) on Helicoverpa virescens and Taman (1990) who mentioned that the maximum and minimum daily temperature were responsible for $23 \%$ and $30 \%$ of the Spodoptera littoralis population density. Also, temperature is an influencing factor affecting the insect life and activity. This factor may be utilized to gain some insight into the size and behavior of field population and consequently into life history and ultimately prediction of future generation (Sevacherian et al., 1977, Ragab, 2009 and Amer et al., 2009). Similarly, Dahi (2007) reported that the prediction of the American bollworm field activities is based on lower threshold of development $\left(T_{0}\right)$, thermal units (DD's) for complete generation, $T_{\max } . T_{\min }$. and catch moths.

It could be concluded that accumulated heat units can be used to predict the American bollworm population before the appearance of its peaks with a positive or negative periods between predicted and actual peaks. For better prediction of the American bollworm, the period between the observed and expected peaks should be positive and as short as possible where early preparation of pest control materials are of great importance. Consequently, it could be helpful when IPM control tactics are considered.

\section{REFERENCES}

1. Amer, A.E., A.A.A. El-Sayed and M.A. Nada. 2009. Development of Helicoverpa armigera (Hub.) (Lepidoptera: Noctuidae) in relation to heat unit requirement. Egypt. J. Agric. Res. 87(3):667-674.

2. Dahi, H.F. 2007. Using heat accumulation and sex pheromone catches to predict the American bollworm, Helicoverpa armigera Hub. field generations. J. Agric. Sci. Mansoura Univ., 32(4): 3037-3044.

3. El-Sayed, A.A.A., Mervat, A. Kandil and A.E. Amer. 2009. Seasonal fluctuation of Helicoverpa armigera (Hübner) (Lepidoptera: Noctuidae) on cotton and okra and heat units related. Egypt. J. Agric. Res., 87(4): 909-921. 
4. Ibrahim, S.S. 2012. Impact of certain new cotton genotypes on ecological and biological aspects of cotton leaf and bollworms. Ph.D. Thesis, Fac. Agric., Cairo Univ., 178 pp.

5. Potter, M.F., R.T. Huner and T.F.Wasion. 1981. Heat unit requirements for emergence of overwingering tobacco budworm, Heliothis virescense (F.) in Arizona. Environ. Entomol., 10: 543-545.

6. Prasad, N.V., M.S. Laskshmi, and N.H. Rao. 2009. Comparative performance of light trap and pheromone traps for monitoring of bollworms in cotton under rainfall situations. Indian J. Ecol., 36(1): 79-83.

7. Ragab, M.G. 2009. Effect of accumulated heat units and cotton fruit structures on larval infestation of Helicoverpa armigera (Hüb.) on cotton and cowpea under different planting systems. Bull. Ent. Soc. Egypt., 86: 249-265.

8. Richmond, J.A., H.A. Thomas and H.B. Hattachargya. 1983. Predciting spring flight of Nantucket pine tip moth (Lepidoptera: Olethreutidae) by heat unit accumulation. J. Econ. Entomol., 76: 269-271.

9. Robinson, H.S. and P.I.N. Robinson. 1950. Some notes on the observed behaviour of Lepidoptera in flight in the vicinity of light sources together with a description of a light trap designed to take entomological samples. Ent. Gaz., 1: 3-20.

10. Sekulic, R., K. Tatfana, S. Masirevic, D. Vajgand, F. Gordana and S. Radojcic. 2003. Incidence and damage of cotton bollworm, Helicoverpa armigera Hub. in Vojvodina province (Serbian) Biljni Lekar, 32(2):113-124.

11. Sevacherian, V., N.C. Toscano, R.A. Van Steenwyk, R.K. Sharma and R.R. Sanders. 1977. Forecasting pink bollworm emergence by thermal summation. Environ. Entomol., 6(4):545-546.

12. Sidde Gowda, D.K., S. Yelshetty, Y.K. Kotikal, B.V. Patil and V.I. Benagi. 2002. Validation of integrated pest management of pigeon pea pod borer, Helicoverpa armigera Chickpea and Pigeon pea. Newsletter, pp. 45-47.

13. Sing,V., R.K. Siag and P. Vijay(2004). Seasonal bionomic of Heliothis armigera $\mathrm{Hb}$. in northern Rajasthan Haryana. J. Aron., 20(12): 62-64.

14. Taman, F.A. 1990. Pheromone trapping of cotton insects in relation to some climatic factors. Alex.Sci. Exch., 11(3): 37-53.

15. Wagner, T.L., H.I. Wu, P.J.H. Sharpe, R.M. Schoolfield and R.M. Coulson. 1984. Modeling insect development rates: A literature review and application of a biophysical model. Ann. Ent. Soc. Amer. 77: 208-225. 


\section{التنبؤ بالأجيال الحقلية لاودة اللوز الأمريكية \\ باستخدام الوحدات الحرارية التراكمية}

جمال على المزين ، محمد جمعة رجب

$$
\text { معهُ بحوث وقاية النباتات ـ الدقى ـ جيزة }
$$

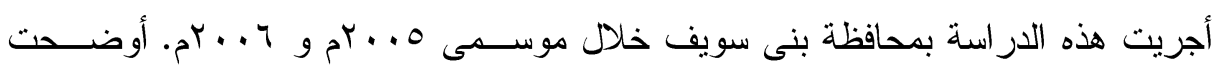

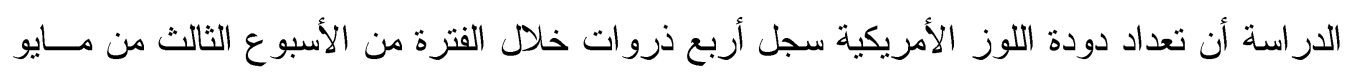
حتى الأسبوع الثانى من سبتمبر فى موسمى الدر اسة.

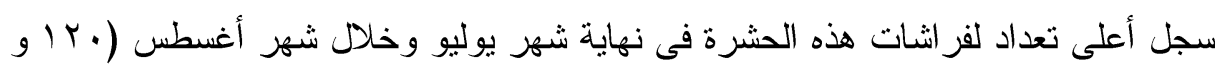

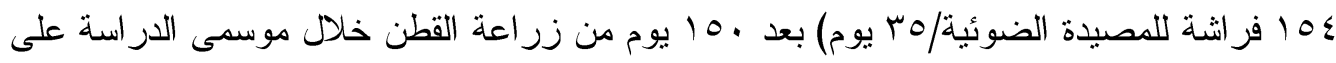

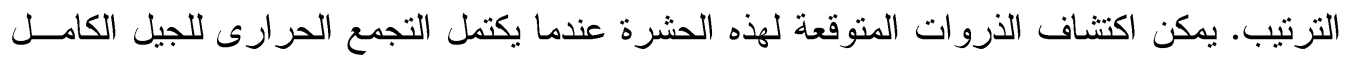

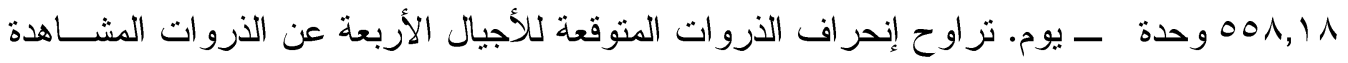

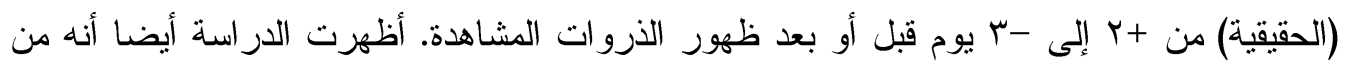

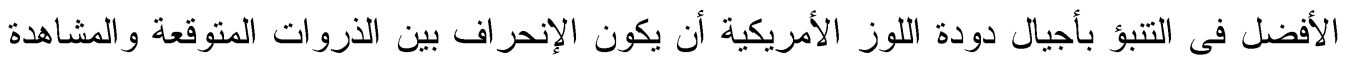

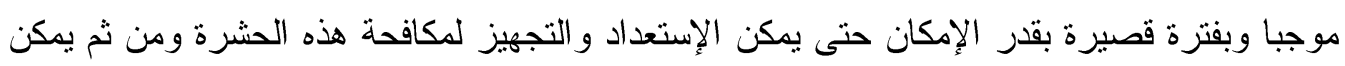

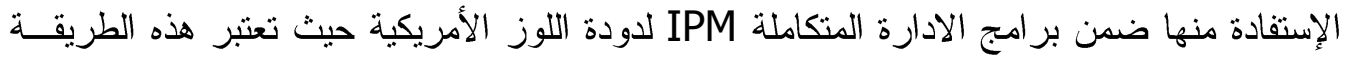

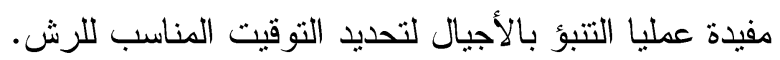

